\title{
A new genus of Erotylidae from Eocene amber (Coleoptera: Clavicornia)
}

\section{Новый род ископаемых жжуков-грибовиков (Coleoptera: Clavicornia: Erotylidae)}

\author{
G.Yu. Lyubarsky ${ }^{1}$ \& E.E. Perkovsky ${ }^{2}$ \\ Г.Ю. Аюбарский ${ }^{1}$, Е.Е. Перковский ${ }^{2}$
}

\footnotetext{
${ }^{1}$ Zoological Museum of Moscow State University Bol'shaya Nikitskaya str. 6, Moscow 103009, Russia. E-mail: lgeorgy@rambler.ru

1 Зоологический музей Московского Государственного Университета, ул. Большая Никитская, 6, Москва 103009, Россия.

2 Schmalhausen Institute of Zoology, Bogdan Chmielnitski str. 15, Kyiv 01601, Ukraine. E-mail: perkovsk@gmail.com

2 Зоологический институт им. И.И.Шмальгаузена, ул. Богдана Хмельницкого, 15, Киев 01601, Украина.
}

KEY WORDS: Erotylidae, Xenohimatium, taxonomy, Late Eocene, Rovno amber.

КЛЮЧЕВЫЕ СЛОВА: Erotylidae, Xenohimatium, таксономия, поздний эоцен, ровенский янтарь.

ABSTRACT. Based on a fossil specimen from the Late Eocene Rovno amber (Ukraine), the Eocene species and genus Xenohimatium rovnense gen.n., sp.n., is described. The new genus is similar to the extant Xenoscelis, differing in procoxal cavities partially open behind; lateral carina on elytra absent; pronotum shorter, without strong excision on anterior margin.

РЕЗЮМЕ. Из позднеэоценового ровенского янтаря (Украина) описан Xenohimatium rovnense gen.n., sp.n. Новый род наиболее близок к современному Xenoscelis, отличается от него частично открытыми сзади передними тазиковыми впадинами, отсутствием боковых килей на надкрыльях, более короткой переднеспинкой, без вырезки по переднему краю.

\section{Introduction}

The family Erotylidae is a group of small and medium size beetles with about 3200 described species in about 280 genera, represented in all biogeographic realms [Wegrzynowicz, 2002; Leschen, 2003]. The classification of the family was most recently revised by Leschen [Leschen \& Wegrzynowicz, 1998; Leschen, 2003], who included the family Languriidae in Erotylidae. The family Erotylidae includes six subfamilies (Xenoscelinae, Pharaxonothinae, Loberinae, Languriinae, Cryptophilinae, and Erotylinae).

Biology of Erotylidae remains very poorly known. Subfamily Erotylinae is mostly mycophagous, while subfamily Languriinae includes phytophagous species. Other subfamilies (Xenoscelinae, Pharaxonothinae, Loberinae, Cryptophilinae) are predominantly mycophagous. Both adults and larvae are commonly found on fungi and under the bark of weakened trees and dead wood, many species feeding on plant debris in forest litter. For example, Cryptophilus Reitter, 1874 and Loberus Leconte, 1861 occurs in leaf litter and mouldy vegetation, and
Leucohimatium Rosenhauer, 1856 is associated with grain crops, feeding on parasitic fungi and smut spores. Other genera are phytophagous or saprophagous, and some species of Xenocryptus Arrow, 1929, Pharaxonotha Reitter, 1875, and Hapalips Reitter, 1877 have been found feeding on the pollen of cycads [Windsor et al., 1999; Leschen \& Buckley, 2007].

Some species are commensals [Leschen \& Buckley, 2007]: Loberopsyllus Martinez \& Barrera, 1966 is associated with rodents [Barrera, 1969; Leschen \& Wegrzynowicz, 1998; Leschen \& Ashe, 1999], Macrophagus Motschulsky, 1845 had been collected from nests of bees; Anthophora Latreille, 1803, Halictus Latreille, 1804 [Horion, 1960], Chasmatodera Arrow, 1943 and Bancous Pic, 1946 (Erotylinae) are found in the nests of social insects [Skelley, 1999; Maryama, 2004], and some erotylid beetles live with fungus-growing termites. Lepidotoramus Leschen, 1997 (Cryptophilinae) may be endoparasitic on lepidopteran pupae [Leschen, 1997]; Nomotus Gorham, 1887 (Languriinae) aggregates with lepidopteran pupae [Windsor et al., 1999].

Late Eocene Rovno amber represents a southern coeval analogue of the famous Baltic amber [Perkovsky et al., 2007; Perkovsky et al., 2010], collected in the northwest of Ukraine. The beetle was found in the sample collected in Klesov or Dubrovitsa in 1999-2000 [Perkovsky et. al., 2007].

\section{Palaeontological data}

Palaeontological data concerning the family Erotylidae were reported by Wegrzynowicz [2002]. A few species of the genera Tritoma Fabricius, 1775 and Dacne Latreille, 1796 have been described from Dominican amber, as well as some Cryptophilus, Dacne, Tritoma (Baltic amber) and Erotylus Fabricius, 1775 (copal) [Poinar, 1992; Skelley, 1997; Spahr, 1981 a,b]. Palaeontological data concerning the subfamily Xenoscelinae or Pharaxonothinae are not available. 
Rovno amber is southern coeval analogue of the famous Baltic amber [Perkovsky et al., 2007; Perkovsky et al., 2010]. Amber collection of the Schmalhausen Institute of Zoology NAN of Ukraine (SIZK) contains more than 1000 inclusions of beetles from Late Eocene Rovno amber.

Photographs were taken at the Paleontological Institute, Russian Academy of Sciences (Moscow) by A.V. Mazin and the second author at the microscope Leica MZ 16 and by A. P. Rasnitsyn at microscope Leica M 165.

\section{Identification of the fossil}

Narrowly elongate, flattened, setose, and reddish brown in colour. Head large; eyes coarsely facetted; lateral pronotal margins simple without crenulate or callosities; tarsi without setose lobes beneath; elytral epipleura well-developed and complete; ventrite 1 not much longer than 2 .
Antennae with 11 segments and a 3-segment club. Supraocular line present. Mesocoxae separated by ca. 0.4-1.0 times of coxal width. Mesocoxal cavities laterally closed by the metaventrite. Tarsal formula: 5-5-5. Epipleuron complete to apex of elytron. Number of ventrites: 5. Abdominal ventrite 1 equal in length to ventrite 2. Consequently, it is placed in the Erotylidae.

Unfortunately, many important characters are not visible (for example, lateral pockets on the mentum, or tarsal shelf of tarsomere 5).

The new genus is related to ones from the basal branch of the family Erotylidae, formerly grouped with Languriidae (Xenoscelinae sensu lato, probably Xenoscelinae or Pharaxonothinae).

The new genus is placed in the subfamily Xenoscelinae based on the following characters: basal pronotal
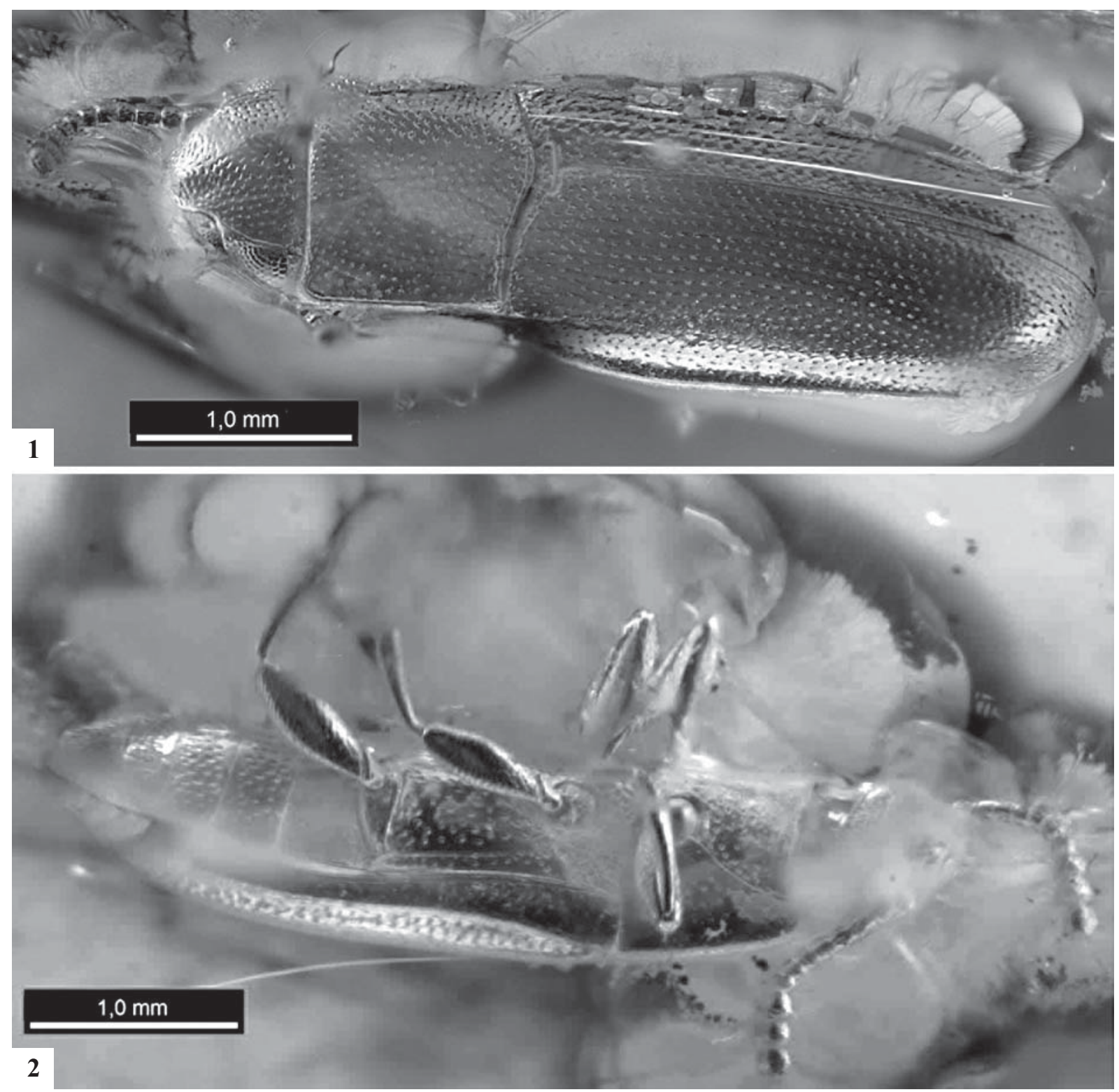

Figs 1-5. Xenohimatium rovnense sp.n., habitus: 1 - laterodorsal view; 2 - lateroventral view.

Рис. 1-5. Xenohimatium rovnense sp.n., внешний вид: 1 - сбоку и сверху; $2-$ сбоку и снизу. 

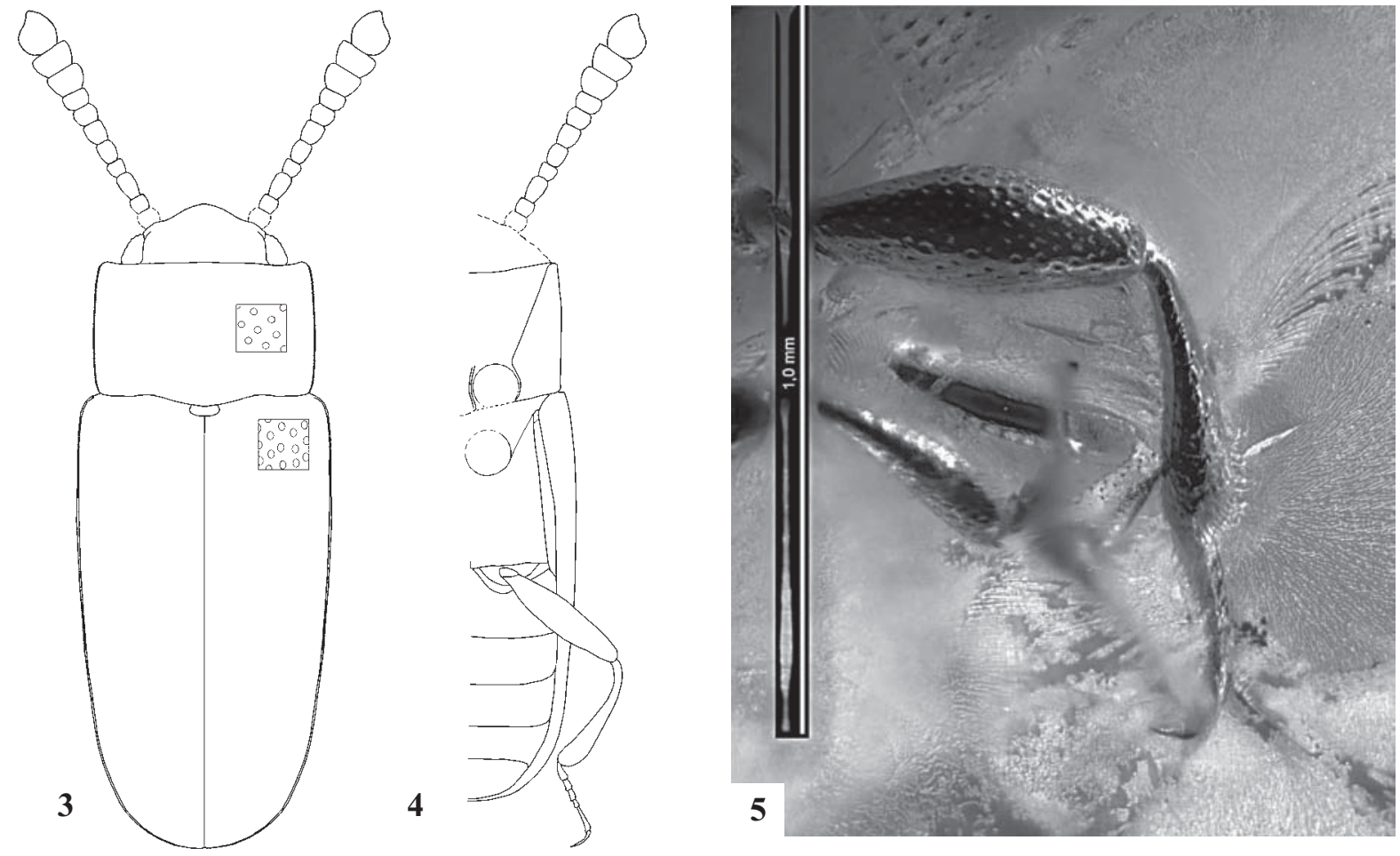

Figs 3-5. Xenohimatium rovnense sp.n.: 3-4 - habitus; 5 - hind tarsus; 3, 5- dosal; 4 - ventral.

Рис. 3-5. Xenohimatium rovnense sp.n. 3-4 - внешний вид; 5 - задняя лапка; 3, 5- сверху; 4 - снизу.

pits absent, partial externally-closed procoxal cavities, tarsomeres not strongly lobed below, elytra with closely spaced rows of punctures, appears covered by confused punctuation, and submesocoxal lines absent.

Family Erotylidae Latreille, 1802

Subfamily Xenoscelinae Ganglbauer, 1899

\section{Xenohimatium Lyubarsky et Perkovsky gen.n.}

Type species: Xenohimatium rovnense sp.n.

DIAGNOSIS. Supraocular line present. Antenna with 11 antennomeres and a 3-segmented club. Antenna long and reaching beyond middle of pronotum. Antennal club not flattened. Antennal insertion not exposed in dorsal view.

Pronotum completely parallel-sided. Anterior angles of pronotum poorly developed, pronotal callosity absent. Lateral margin of pronotum not serrate, smooth. Dorsal punctation weak, dorsum subglabrous. Anterior edge of prosternum almost smooth. Pronotal pits absent.

Internal closure of procoxal cavity slightly open. Width of mesoventral process narrower than mesocoxa. Submesocoxal lines absent. Metepisternal ctenidium present.

Tarsi 5-5-5. Length of tarsomere 1 greater than tarsomere 2. Tarsomeres 2 and 3 not lobed. Tarsomere 4 not reduced.

Scutellum transverse. Elytral punctation striate. Elytra narrowly explanate. Humeral spine absent. Epipleuron complete to apex of elytron.

Abdominal ventrites 1 and 2 free.

COMPARISON. Differs from genera of the family Erotylidae (Xenoscelinae, Pharaxonothinae):

- from genus Leucohimatium in the absence of callosity on the anterior angles of pronotum;

- from genera Loberonotha Sen Gupta et Crowson, 1969,

Macrophagus, and Othniocryptus Sharp, 1900 by rows of punctures of elytra, and weak pubescence of the body;

- from genera Pharaxonotha, Henoticonus Reitter, 1878, Xenocryptus, and Zavaljus Reitter, 1880 by pronotum completely parallel-sided;

- from genus Loberogosmus Reitter, 1876 by pronotal pits absent, metepisternal ctenidium present, tarsomere 3 not lobed;

- from genus Xenoscelis Wollaston, 1864 by procoxal cavities partially open behind; lateral carina on elytra absent; pronotum shorter, and without strong excision on anterior margin.

New genus is related to Xenoscelinae sensu lato, close to Xenoscelinae. Unfortunately many characters are not visible, for example structure of mouth parts, vertexal line, hind wing etc.

ETYMOLOGY. The genus name is grammatically neuter. It is compounded from parts of two other genus names, Xenoscelis and Leucohimatium.

Xenohimatium rovnense Lyubarsky et Perkovsky sp.n. Figs 1-5

MATERIAL. Holotype, SIZK UA-449, Rovno amber, Late Eocene. Syninclusions: 3 Acari (2 Glaesacarus); Homoptera: Ortheziidae.

DESCRIPTION. Body elongate-oval, length $2.6 \mathrm{~mm}$. Colour light-brown.

Head and pronotum with very short hairs. Size of eye less than half length of head. Diameter of facet equal to $0.001 \mathrm{~mm}$. Shape of eye hemispherical. Punctuation of head: punctures medium in size, distance between neighbouring punctures equal to one diameter of puncture.

Pronotum without callosity and teeth, width to length ratio 1.55. Width of pronotum greater than its length, not narrower than the combined width of the elytra. Anterior margin of pronotum without deep excavation, only slightly sinuated. Lateral margins are parallel. Punctuation with small punctures, the distance between them is 1.0-1.5 diameter of puncture. Prono- 
tum slightly shagreened. Length of pronotum relative to length of elytra 0.33. Posterior angles obtuse. Basal furrow absent.

Legs slender, length of posterior tarsus shorter than length of posterior tibia. Length of posterior tarsus comparative to length of middle tarsus: equal.

Elytral pubescence short. Length of hair less than breadth of scutellum. Elytra covered by rows of punctures, distance between neighbouring punctures equal to 2 diameters of puncture.

Elytral length 1.8 times greater than width. Tooth on schoulder absent. Sutural stria extending beyond the middle of the disk. Epipleuron visible from above.

ETYMOLOGY. Rovnensis (neuter: Rovnense) is the traditional Latin adjective meaning "related to the city (or Oblast, or Region) of Rivne (Rovno)".

REMARKS. Although reliable data on biology of Xenohimatium gen.n. are absent, an analysis of some structural features of the beetle allows to make some conclusions. If reconstruction of Leschen and Buckley [Leschen \& Buckley, 2007] of the primary diet of Erotylidae is true, we should assume that the new genus, placed at the root of the erotylid tree, was characterized by microfungal feeding or saprophagy, or pollen feeding. As for relations with plant associations, the primitive erotylids were associated with cycads and conifers [Leschen \& Buckley, 2007].

For example, Pharaxonotha confusa Pakaluk occurs in Zamia fairchildiana cones in Costa Rica [Pakaluk, 1988], and congeners are known to be associated with other Zamia in Florida and Mexico [Tang, 1987; Vovides, 1991]; Xenocryptus tenebrioides Arrow, 1929 occurs in Macrozamia cones. Hapalips sp. in male Cycas cones in Australia [Ornduff, 1991]; Nomotus spp. feed on Zamia leaves [Windsor et al., 1999].

Leschen and Buckley [Leschen, 2006; Leschen \& Buckley, 2007] hypothesize about changing food preferences of the family Erotylidae and general directions of the evolution of the group. There is a network of transitions connecting the microfungal diet original for the group and derived types of saprophagy, pollenophagy, phytophagy, and feeding on dead wood. These authors believe that the evolution of the family Erotylidae was closely associated with cycads (Cycadales) [Jolivet, 2005]. However, as it turns out, cycads are now considered a relatively young group. Cycads are thought to have undergone a near-synchronous global rediversification beginning in the late Miocene, followed by a slowdown toward the Recent [Nagalingum et al., 2011; Renner, 2011]. A variety of cycads have passed through the bottleneck of 10-12 million years ago, which may affect our understanding of the evolution of the associated Erotylidae and other groups of Coleoptera.

Fossil Eocene cycads are known from Fushun in Northern China (famous by its amber fauna), Japan and Australia. Interestingly, the new erotylid is found with an ortheziid female, never found previously with other Rovno amber beetles; coccids are known as important pests of cycads.

ACKNOWLEDGEMENTS. We are grateful to Alexandr Rasnitsyn and Alexandr Mazin for kindly taking photographs of the specimen.

\section{Reference}

Barrera A. 1969. Notes on the behaviour of Loberopsyllus traubi, a cucujoid beetle associated with the volcano mouse, Neotomodon alstoni in Mexico // Proceedings of the Entomological Society of Washington. Vol.71. No.4. P.481-486.

Horion A. 1960: Faunistik der mitteleuropäischen Käfer. Band VII: Clavicornia. Teil 2. (Sphaeritidae bis Phalacridae). Teredilia, Coccinellidae. Überlingen, A.Feyel. xiii +375 pp.
Jolivet P. 2005. Cycads and beetles: recent views on pollination // The Cycad Newsletter. Vol.28. P.3-7.

Leschen R.A.B. 1997. The Empocryptus-group (Languriidae: Toraminae) and a new genus associated with a lepidopteran cocoon // Coleopterists Bulletin. Vol.51. P.303-318.

Leschen R.A.B. 2003. Erotylidae (Insecta: Coleoptera: Cucujoidea): Phylogeny and review // Fauna of New Zealand. Vol.47. P.1-108.

Leschen R.A.B. 2006. Evolution of Saproxylic and Mycophagous Coleoptera in New Zealand P.1-8 // S.J. Grove \& J.L. Hanula (Eds.) Insect biodiversity and dead wood: proceedings of a symposium for the 22nd International Congress of Entomology. Gen.Tech.Rep. SRS-93. Asheville, NC: U.S. Department of Agriculture, Forest Service, Southern Research Station. 109 p.

Leschen R.A.B. \& Ashe J.S. 1999. New species, phylogenetic placement, and mammal associations of Loberopsyllus (Languriidae: Xenoscelinae). P.171-177 // G.W. Byers, R.H. Hagen, \& R.W. Brooks (Eds.) Entomological contributions in Memory of Byron Alexander. University of Kansas Natural History Museum Special Publication. Vol.24.

Leschen R.A.B. \& Buckley T.R. 2007. Multistate Characters and Diet Shifts: Evolution of Erotylidae (Coleoptera) // Systematic biology. Vol.56. P.97-112.

Leschen R.A.B. \& Wegrzynowicz P. 2008. Arrowcryptus, a new genus of Xenoscelinae of Erotylidae from Africa // Zootaxa. Vol.1968. P.45-57.

Maryama M. 2004. Chasmatodera grata, a New Termitophilous Pleasing Fungus Beetle from Thailand (Coleoptera, Erotylidae, Tritominae) // Japanese Journal of Systematic Entomology. Vol.10. No.2. P.223-226.

Nagalingum N.S., Marshall C.R., Quental T.B., Rai H.S., Little D.P \& Mathews S. 2011. Recent synchronous radiation of a living fossil // Science. Vol.334. P.796-799.

Ornduff F. 1991. Coning phenology of the cycad Microzamia riedlei (Zamiaceae) over a five year interval // Bulletin of the Torrey Botanical Club. Vol.118. P.6-11.

Pakaluk J. 1988. Review of the New World species of Pharaxonotha Reitter (Coleoptera: Languriidae) // Revista de Biologia Tropical. Vol.36. No.2B. P.447-451.

Perkovsky E.E., Rasnitsyn A.P., Vlaskin A.P. \& Taraschuk M.V 2007. A comparative analysis of the Baltic and Rovno amber arthropod faunas: representative samples // African Invertebrates. Vol.48. No.1. P.229-245.

Perkovsky E.E., Zosimovich V.Yu. \& Vlaskin A.P. 2010. Rovno Amber in Biodiversity of fossils in amber from the major world deposits // D. Penney (Ed). Siri Scientific Press, Manchester, 2010. P.116-136.

Poinar G.O. 1992. Life in Amber. Stanford: Stanford University Press. XIII + 350 pp.

Renner S.S. 2011. Living fossil younger than thought // Science. Vol.334. P.766-767.

Skelley P.E. 1997. A new species of Dacne Latreille from Dominican amber, with a key and checklist to known species of Dacne (Erotylidae: Dacninae) // Annales Zoologici. Vol.47. No.1/2. P.49-53.

Skelley P.E. 1999. Termitophilous pleasing fungus beetles: Chasmatodera Arrow and Rhamphidera Skelley, gen. nov. (Coleoptera: Erotylidae: Tritominae) // Annales Zoologici. Vol.49. No.3. P.255-263.

Spahr U. 1981a. Bibliographie der Berstein- und Kopal-Käfer (Coleoptera) // Stuttgarter Beiträge zur Naturkunde, Serie B (Geologie und Paläontologie). Bd.72. S.1-21.

Spahr U. 1981b. Systematischer Katalog der Berstein- und KopalKäfer (Coleoptera) // Stuttgarter Beiträge zur Naturkunde, Serie B (Geologie und Paläontologie). Bd.80. S.1-107.

Tang W. 1987. Insect pollination in the cycad Zamia pumila (Zamiaceae) // American Journal of Botany. Vol.4. No.1. P. $90-99$.

Vovides A.P. 1991. Insect symbionts of some Mexican cycads in their natural habitat // Biotropica. Vol.23. No.1. P.102-104.

Wegrzynowicz P. 2002. Morphology, phylogeny and classification of the family Erotylidae based on adult characters (Coleoptera: Cucujoidea) // Genus. Vol.13. No.4. P.435-504

Windsor D., Ness J., Gomez L. D. \& Jolivet P. 1999. Species of Aulacoscelis Duponchel and Chevrolat (Chrysomelidae) and Nomotes Gorham (Languriidae) feed on fronds of Central American Cycads // Coleopterists Bulletin. Vol.53. No.3. P.217-231. 